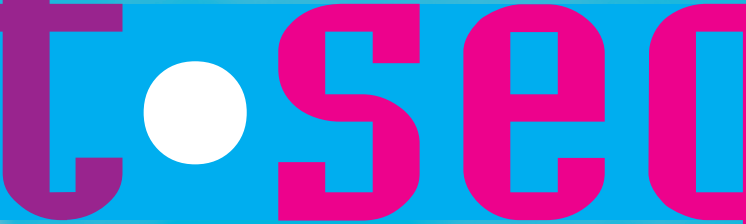

The Low Countries Journal jaargang 17

of Social and Economic 2020

History

nummer 3

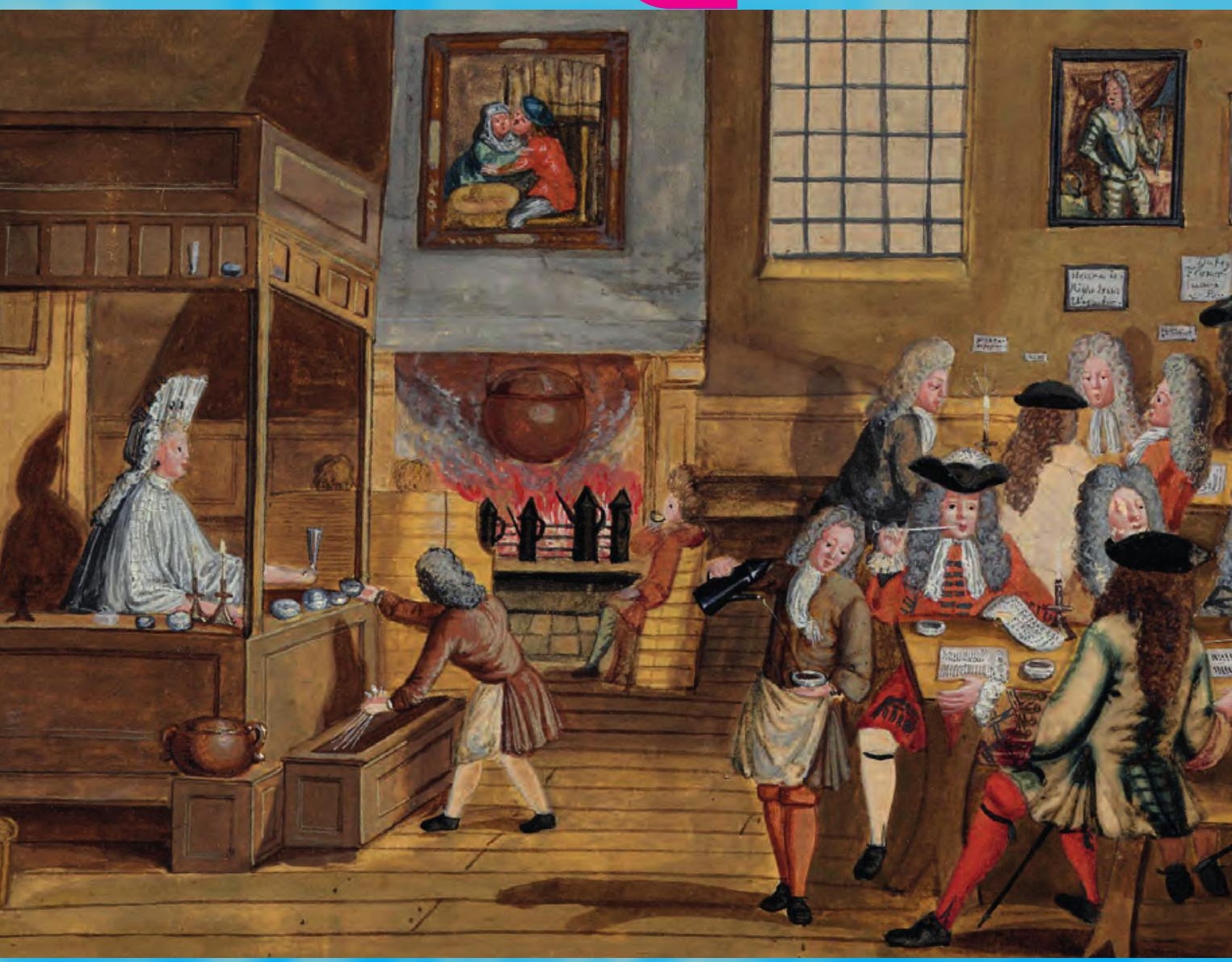

- Newcomers, Migrants, Surgeons [Groot]

- In Vino Veritas [Walschap]

- Dossier Maarten Prak's Citizens without Nations - a Debate

- Boeken over de Tweede Wereldoorlog [Lak] 


\title{
Citizens without Nations - a Clarification
}

\author{
Maarten Prak
}

TSEG 17 (3): 121-130

DOI: $10.1835^{2} /$ tseg. 1170

My book Citizens without Nations might be read as a triple provocation, as it challenges three received wisdoms of historical textbooks. The first, and perhaps most fundamental, is the idea that the grand narratives of the past have to be the histories of nations and their states. Of course, numerous histories of regions and localities have been written during the past half century. Urban history, for example, was invented in the 1960 os in the United Kingdom as a sub-branch of social history. ${ }^{1}$ It has produced, beyond numerous studies of individual towns, wonderful surveys, but without the ambitions of rewriting the general history of Europe or other parts of the world. ${ }^{2}$ Citizens without Nations utilizes hundreds of those local studies to challenge, perhaps foolishly, a major element of the modernization narrative. This paradigm portrays European politics as neatly subdivided by the French Revolution. Before 1789 , ordinary people were only occasionally and intermittently involved in politics and administration, which was the realm of elites. The latter were corrupt exploiters of their subjects. In England this already changed with the Glorious Revolution of 1689 , but even there a small clique of noble and gentry families completely dominated public life, according to the textbook version of history. In the book I tell the political history of medieval and early modern Europe from the perspective of urban citizens, and claim that the picture is very different from what the textbooks like us to believe. Instead, urban citizens were actively involved in the administration of their home towns, but also participated in a much broader set of practices that provided them with a lot of

1 S. Ewen, What is urban history? (Cambridge 2016) Ch. 1 and passim.

2 P. Clark, European cities and towns 400-2000 (Oxford 2009), with more English-language titles in its bibliography; P. Boucheron and D. Menjot, La ville médiévale, Histoire de l'Europe urbaine vol. 2 (Paris $2011)$; O. Zeller, La ville moderne XVI-XVIII siècle, Histoire de l'Europe urbaine vol. 3 (Paris 2012). 
'agency'. ${ }^{3}$ In France and other countries occupied by the revolutionary French, the local institutions supporting this agency were destroyed during and after the Revolution.

The second textbook history challenged by Citizens without Nations is that the French Revolution was for most people an improvement. Having had little or nothing to say about the way they were ruled, or the selection of their rulers, the revolutionary reforms at least acknowledged the right of ordinary people to be heard. This was the result of an overhaul of the system of rule that abolished constraining privileges and the petty elites that maintained them, and instead promised more freedom and a major role for citizens. Unfortunately, the revolutionaries were slow to deliver on these promises. It took, I argue, in fact the best part of a century to create new institutional challenges to the authorities to replace those that had been available to citizens in many towns and cities across Europe. In many textbooks this is glossed over, because of the assumption that even in its limited form, the democracy delivered by the revolutionaries was an improvement. It probably was compared to the previous system of national rule, but if we take into account the local situation, it is difficult to be so convinced of the benefits of the French Revolution, at least in the short and medium term.

Whereas the first two challenges, and indeed the largest part of the text, were concerned with the history of Europe, the third challenge seeks to redefine Europe's place in the world. Again, the idea that Europe cannot be the benchmark against which the rest of the world's history can be measured, is obviously not so new. Remarkably few books, however, seek to compare the socio-institutional history of Europe with other world regions. In doing so, Citizens without Nations demonstrates that, despite major differences in their systems of rule, not only the European colonies in the Americas, but also the empires of China and the Middle East displayed citizenship practices not unlike those of Europe. This undermines the idea, going back to the great sociologist Max Weber, that Europe's superior institutional structures propelled that continent into a leading role on the world stage.

Challenges to received wisdom only make sense when they are read and challenged in turn. My book was explicitly conceived as part of an intellectual conversation. I am grateful to the editors of the TSEG - The Low Countries Journal of Social and Economic History for creating the space, and for inviting four eminent historians, to pick up the gauntlet

3 J.L. van Zanden, A. Rijpma and J. Kok (eds.), Agency, gender, and economic development in the world economy, $1850-2000$ (Basingstoke 2017) 1-2, 12-13, 52-53. 
and raise their concerns about some of my ideas. ${ }^{4}$ That they do not reject them outright, is both a relief and reassuring. For the sake of honesty and transparency I should state that the work of three of them has been a help and an inspiration when I wrote my chapters on England (Phil Withington), Spain and the Spanish colonies in the Americas (Tamar Herzog), and China (Christine Moll-Murata). I was so far unaware of Catherine Coquery-Vidrovitch's work on Africa, but I have come to appreciate her contribution as a result of her review essay. I am profoundly grateful to all four for their contributions. I cannot possibly respond to all the points raised by their rich reviews, and have therefore decided to pick out one substantive point from each of them to structure my clarifications. From among Withington's especially rich comments I have chosen to focus on the possibly overly optimistic picture I have drawn of local citizenship, while Herzog rightfully raises concerns about my portrayal of 1789 as a turning point in European history, and its implications. For China's institutional history, two new books, one of them written by Moll-Murata, offer opportunities to test my picture of the Chinese situation. Finally, Coquery-Vidrovitch's comments provide an opportunity to explain the absence of Africa in my book.

Before I turn to the core of Withington's critique of my book I want to set out my own objections to Habermas's description of the public sphere, a critique that comes close to Withington's own position, even if his has been more profoundly researched and more elegantly stated. ${ }^{5}$ Habermas equated the emergence of a public sphere with the Enlightenment in two distinct ways. He saw this as an era of a new sociability, in the salons and coffee-houses as they emerged from the late seventeenth century. Participation in these activities was voluntary and therefore Habermas chose to distinguish them from the earlier sociability of guilds, confraternities and civic militias. Apart from the fact that membership of confraternities was usually also voluntary, ${ }^{6}$ the distinction seems to miss the point that these were three contexts that organized huge numbers of people who identified themselves a citizens,

4 A similar discussion has been published in the International Review of Social History 65:1 (2020), 99-142, with contributions from Katherine A. Lynch, Jack A. Goldstone and R. Bin Wong; see also substantive reviews by Gerd Schwerhoff in H/Soz/Kult, June 2019 (https://www.hsozkult.de/review/id/ reb-276o8); Christopher Friedrichs in American Historical Review 125:2 (2020) 6o4-6o6; Jos C.N. Raadschelders in Public Administration Review 80:3 (2020) 516-517.

5 P. Withington, 'Public discourse, corporate citizenship, and state formation in early modern England', The American Historical Review 112:4 (2007) 1024-1026 and passim.

6 See, e.g., G. Rosser, The art of solidarity in the Middle Ages. Guilds in England 1250-1550 (Oxford 2015). 


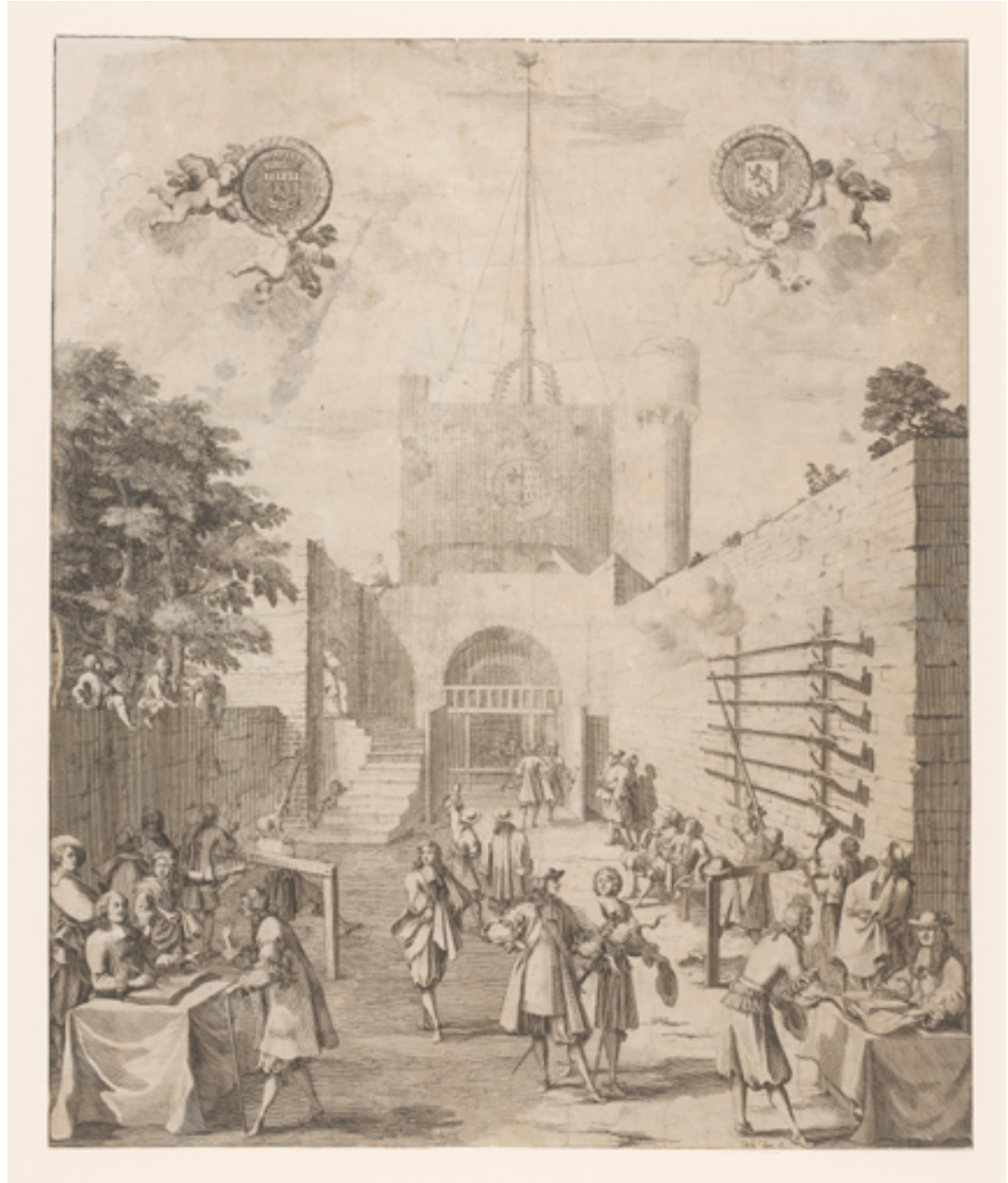

Illustration 1 The civic milita of Nantes (Les tireurs de Nantes) around 1668, pictured by Sebastien Leclerc (source: Collection Rijksmuseum Amsterdam).

contexts that spawned collective action, underpinned by an idea about these activities that is discussed in my book as 'urban republicanism. ${ }^{7}$ Habermas's portrayal of an interest in public affairs emerging only in the eighteenth century is therefore fundamentally flawed. This is like-

7 The best discussion of this 'urban', or 'civic' republicanism is H. Schilling, 'Civic republicanism in late medieval and early modern German cities', in: Idem, Religion, political culture and the emergence of early modern society. Essays in German and Dutch history (Leiden 1992) 3-59 (original title 'Gab es im späten Mittelalter und zu Beginn der Neuzeit in Deutschland einen städtischen "Republikanismus"? Zur politische Kultur des alteuropäischen Stadtbürgertums', in: H. Koenigsberger (ed.), Republiken und Republikanismus im Europa der Frühen Neuzeit (Munich 1988) 101-143). 
wise true of his portrayal of the media. Newspapers began to be published during the first quarter of the seventeenth century, but they were preceded by pamphlets, which had the purpose of articulating positions on public issues. In other words, well before the eighteenth century urban citizens cared about public affairs, had access to written information and opinions on these affairs, and were organized in ways that allowed them to act on their opinions. From the high Middle Ages, in other words, they were genuine citizens. Habermas's ideas belong, in my view, to a historical narrative that sees the Enlightenment as the start of 'modernity', a narrative launched, of course, by the French revolutionaries themselves. As the destroyers of urban citizenship, its organizations, practices and ideas, the revolutionaries had every reason to portray it as a backward, indeed feudal, institution. My book is an attempt to reverse this verdict.

Indeed, as my objections to Habermas's ideas should make clear, I tend to think more positively of these institutions than has usually happened since 1789 . I am not the first to do so: catholic social theorists and fascists, for example, have preceded me. ${ }^{8}$ I hope, however, that I have not praised the pre-1789 forms of urban citizenship because they represent the harmonious Volk that these precedents were hankering for. Instead, I like to think of my book as a critique of the nationalist ideas that such catholic and fascist thinkers were hoping to provide with a historical role model, specifically the guild, that gave their own ideas at one and the same time a long pedigree and inroads into the world of socialism. For the early labour movement, the guild was a role model because it suggested that until the eighteenth century labourers had been organized and as a result in charge of their own fate. ${ }^{9}$ My own evaluation comes closest to this socialist idea of empowerment, for labourers as much as other 'ordinary folk' in general. I also share with the early labour movement a suspicion of, not so much big business, but big state, as it was created by the reforms of the French Revolution. I appreciate the greater equality the modern state has created in the long run, but in this day and age we must also acknowledge the price that has

8 The point was made in a review by Chris van der Heijden of the Dutch translation of my book, and Wim Blockmans' work Medezeggenschap in the Dutch weekly De Groene Amsterdammer 2020, issue 9 (26 February), 'Het is niet wat het is'.

9 E.g. A. Knotter, Transformations of trade unionism. Comparative and transnational perspectives on workers organizing in Europe and America, eighteenth to twenty-first Centuries (Amsterdam 2018) Ch. 3 (original title "Van "defensieve standsreflex" tot "verkoopkartel van arbeid". Twee fasen in de ontwikkeling van de Amsterdamse arbeidersvakbeweging (ca. 1870 - ca. 1895)', Tijdschrift voor Sociale Geschiedenis 19:1 (1993) 68-93). 
been paid: bureaucracy and the new inequalities and alienation that have emerged in part as a result of precisely the increased scale of political processes. I hope I have not overlooked the injustices and exclusions that were incorporated in the urban citizenship described in my book. Being aware of these shortcomings, I deliberately chose not to present urban citizenship as an alternative to national citizenship for our own times. That would, in my view, undo the genuine progress of the past two centuries in areas such as political representation and social protection. Instead, I propose to add local citizenship to the combination of national and EU citizenship that is currently under development in Europe, and suggest that it might serve as a model outside Europe as well..$^{10}$ I agree that there is an element of idealism in this recommendation, but this, to my mind, is one of the things historians owe to society: articulate the societal implications of their work where that is possible. For me, the history of local citizenship offered an opportunity to do so. Therefore, I am happy to plead guilty to the charge.

Tamar Herzog's discussion of the Spanish situation raises questions about the second claim of my book, which relates to the impact of the French Revolution. Did it indeed terminate the role of towns and cities all over Europe? Her Spanish materials show that it did not and that in fact only in the twentieth century Spanish national politics subjugated local politics. Spain, of course, was never properly conquered by Napoleon's armies, so the impact of the French reforms remained superficial. This was also true, albeit to various extents, in Germany and Switzerland (both occupied). ${ }^{11}$ Even in the Netherlands, not only occupied but for some time completely incorporated into the French state, the impact of the French reforms is far from straightforward. Some recent research suggests that local institutions retained substantial agency well into the nineteenth century, in spite of constitutions and other rules designed to deny them precisely this. ${ }^{12}$ It still seems fair to say that in the long run local authorities everywhere in Europe, with the possible exception of the Swiss Confederacy, lost out to national authorities, but this was a much more convoluted process than my emphasis on 1789

10 See: F. Cheneval and M. Ferrín (eds.), Citizenship in segmented societies. Lessons for the EU(Cheltenham 2018).

11 E.g. L. Gall (ed.), Vom alten zum neuen Bürgertum. Die mitteleuropäische Stadt im Umbruch $1780-$ 1820 (Munich 1991); M. Lerner, A laboratory of freedom. The transformation of political culture in republican Switzerland, 1750-1848 (Leiden 2012).

12 J. Pollmann and H. te Velde, 'New state, new citizens? Political change and civic continuities in the Low Countries, 1780-1830', BMGN - Low Countries Historical Review 133:3 (2018) 4-23; W. van Schaik, In de maat en uit de pas. Utrechtse dorpsbesturen 1780-1830 (Hilversum 2019). 
as a turning point has suggested. ${ }^{13}$ And as Herzog's contribution underlines, the 'long run' could amount to a century-and-a-half or more, i.e. some six generations. What caused this delay? In the Netherlands, I would argue, the state's incapacity to fulfill its own ambitions was crucial. A couple of hundred civil servants were unable to control in great detail what was going on in the communities. As in imperial China, the actual span of control of central authorities around 1800 or 1850 did not match their ideas. In Switzerland, the regions had never collaborated very closely and therefore few elite families were keen to associate their fate with central government at the expense of their virtually independent territories. ${ }^{14}$ Perhaps the whole issue of central-versus-local is une question mal posée. Ideas about multi-level governance may be more effective in thinking about the institutional trajectories that states traversed since the late eighteenth century. ${ }^{15}$

Two of the three parts in Citizens without Nations are devoted to Europe. The final part, consisting of only two chapters, discusses non-European regions: one of these is about the Chinese and Ottoman empires, the other about European colonies in the Americas. The Asian empires were chosen because they represented a system of rule (imperial) that was centralized to a point hardly present in medieval or early modern Europe. They represented the sort of situation that authors like Max Weber, and many following in his footsteps, considered 'typically' Asian. In the Americas, on the other hand, it would be possible to observe how the European brand of citizenship fared under colonial circumstances. Because these were for me the most challenging parts of the book, I am especially pleased to have two commentators focusing on these non-European elements. It is even more pleasing that they both support the general point that I am making, which is that the 'citizenship practices' I described for European towns and cities were indeed found in China, but also in Africa.

13 Compare Marcel Hoogenboom, Christopher Kissane, Chris Minns, Maarten Prak and Patrick Wallis, 'Guilds in the transition to modernity. The cases of Germany, United Kingdom and the Netherlands', Theory \& Society 47 (2018) 255-291.

14 Switzerland still is an intriguing case, because it challenges the idea that modern and successful states require nationally centralized governance. See: F. Cheneval and M. Ferrín, 'Switzerland as a model for the EU', in: Idem (eds.), Citizenship in segmented societies, 10-39, as well as A. Holenstein, T. Maissen and M. Prak (eds.), The republican alternative. The Netherlands and Switzerland compared (Amsterdam 2008).

15 A.H. Schakel, L. Hooghe and G. Marks, 'Multi-level governance and the state', in: S. Leibfried, E. Huber, M. Lange, J.D. Levy, and J.D. Stephens (eds.), The Oxford handbook of transformations of the state (Oxford 2015) 269-285. 
Since I wrote my book, two relevant works on Chinese history have appeared that I would like to see as a confirmation of the general drift of my argument. In The Art of Being Governed Michael Szonyi utilizes family records to demonstrate how in China ordinary people handled the state's demand for soldiers. ${ }^{16}$ Military service in China was compulsory, but usually comprised one male per family or even combination of families. Which male would be selected for this onerous duty, but, more importantly, how families dealt with the demands of the state, was subject to a lot of different factors which gave those families significant agency. In other words, Szonyi too sees the interactions between the Chinese state and its subjects as open to negotiation, as I did in my book. Christine Moll-Murata herself published her full-length study of Chinese guilds, which for me were an important reason to see parallels between the situation in Chinese and European towns and cities, even if European guilds are not identical to those in China. ${ }^{17}$ In her contribution to this TSEG issue, she is also suggesting that Chinese towns had their own formal citizenship, publicly documented, something I denied in my book. I agree that this Chinese registration established in itself certain rights, but it nonetheless was not, I think, the same as the formal citizenship of pre-modern Europe. At times, European towns also registered all households, usually for purposes of taxation. Urban dwellers, irrespective of their formal status, could expect their property rights to be respected, and were entitled to a fair trial: the same as in China, it seems. However, on top of this, the inhabitants who had formal citizenship in European towns also enjoyed some additional rights. ${ }^{18}$ They were eligible for office, were entitled to vote in elections where these were held, and only they could join a guild. In some towns some social facilities, like high-quality orphan care in Amsterdam and other Dutch towns, were only accessible to full citizens. ${ }^{19}$ This distinction between those with (citizens) and those without (inhabitants) formal status seems to have been unknown in China.

Apart from the fact that the regions I chose gave me an opportunity to highlight some specific aspects of my topic, another, more practical consideration also determined the selection of regions outside Eu-

\footnotetext{
16 M. Szonyi, The art of being governed. Everyday politics in late imperial China (Princeton 2017). 17 C. Moll-Murata, State and crafts in the Qing dynasty (1644-191 1 ) (Amsterdam 2018). 18 M. Prak, Citizens without nations. Urban citizenship in Europe and the world, c. 1000-1789 (Cambridge 2018) Ch. 1.

19 A.E.C. McCants, Civic charity in a Golden Age. Orphan care in early modern Amsterdam (Urbana 1997).
} 
rope. For China and the Middle East (including parts of North Africa), I could access relevant studies, moreover in languages that I could read. I did consider other parts of Asia, specifically Japan and India, and found the literature too limited for my purpose and linguistic capacities. My search was perhaps too superficial. With the same objective in mind, I also considered sub-Saharan Africa.

At this point, I should explain that my book relies almost exclusively on local studies of urban history. In Europe, this field has blossomed during the past decades. The Asian and American countries and regions I discussed in my book offered a comparatively smaller number of relevant studies than I could use for Europe, but still enough to get a sense of citizenship practices. For pre-colonial Africa such studies seem to be sadly lacking. I consulted general works that demonstrate the importance of urban life to the history of pre-colonial Africa. ${ }^{20}$ The Hausa and Yoruba city-states, both roughly in what is now Niger and Nigeria and both coinciding with the time-frame of my book, would have been obvious case-studies to include. ${ }^{21}$ Unfortunately, the literature on these city-states has little to say about the role of citizens in the ruling of their cities. The Hausa had guilds, but I have not been able to find much about them. ${ }^{22}$ No doubt, this is partly explained by legacies of colonialism, but there is also the situation of the sources to consider. Compared to historians of Europe and Asia, historians studying Africa can rely less on medieval and early modern documents, and where those exist they have often been written by outsiders, for example European travelers. Instead, historians of sub-Saharan Africa have to depend more on oral traditions and archeological material. ${ }^{23}$ Unfortunately, these latter sources are not strong on the sort of information I needed. It is reassuring to hear from an expert as distinguished as Coquery-Vidrovitch that she thinks my ideas will be applicable in Africa south of the Sahara. It would, I suspect, nonetheless require an additional effort to transform

20 G. Connah, African civilizations. Precolonial cities and states in tropical Africa. An archeological perspective (Cambridge 1987); B. Freund, The African city. A history (Cambridge 2007); I should also have looked at C. Coquery-Vidrovitch, A history of African cities from the origins to colonization (Princeton 2005) (original title Histoire des villes d'Afrique noire. Des origines à la colonisation (Paris 1993)). See also C. Coquery-Vidrovitch, 'The process of urbanization in Africa (from the origins to the beginning of independence)', African Studies Review 34:1 (1991) 1-98.

21 R. Griffeth, 'The Hausa city-states from 145 o to 1804', and J.D.Y. Peel, 'Yoruba as a City-State Culture', both in: M. Herman Hansen (ed.), A comparative study of thirty city-state cultures. An investigation conducted by the Copenhagen Polis Centre (Copenhagen 2000), 483-506 and 507-517 respectively.

22 Griffeth, 'The Hausa city-states', 494.

23 Connah, African civilizations, 73-75, 102-103, 128-129, 158-159, 189. 
this conviction into substantial evidence and flesh out the details that will allow us to also appreciate in which areas African cities followed their own trajectories.

I would consider the publication of Citizens without Nations a success when it managed to encourage other historians to investigate the book's blind spots: the role of religion, the impact on gender, the political culture of the countryside, world regions so far not covered. Obviously, the book's claims will also be challenged in areas that have been covered more substantially between its covers. I will be proven wrong in various ways. If such challenges lead to an improved understanding of the role of citizens in the shaping of their own and ultimately also our world, who would want to complain?

\section{About the author}

Maarten Prak is Professor of Social and Economic History at the Department of History and Art History, Universiteit Utrecht, The Netherlands.

E-mail:m.prak@uu.nl 


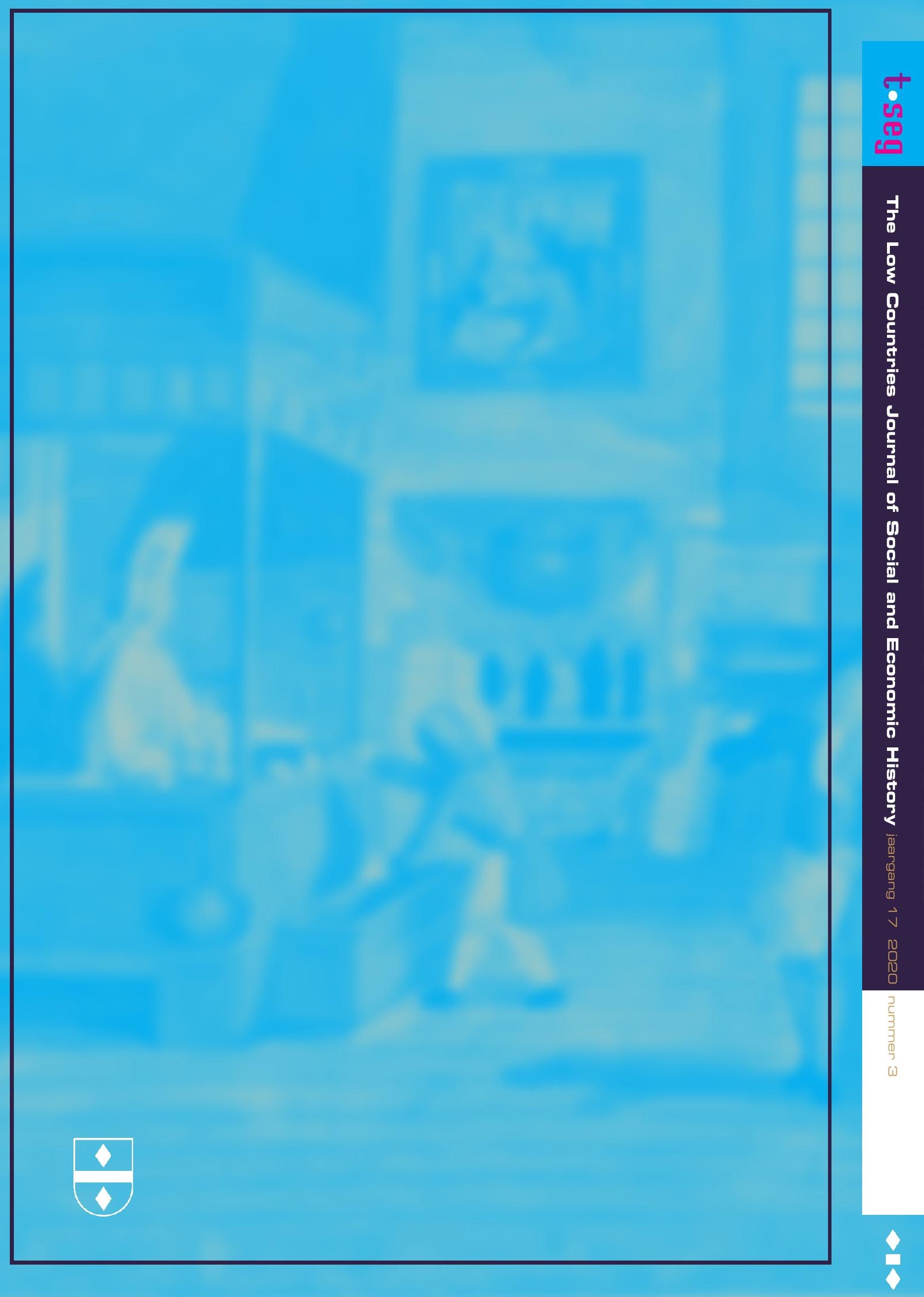

